\title{
Problematyka pracy w badaniach z zakresu geografii społeczno-ekonomicznej w Polsce i krajach anglosaskich
}

\section{The issue of labour research in the field of socio-economic geography in Poland and in the Anglophone countries}

Streszczenie: Rynek pracy wraz z mechanizmami jego funkcjonowania był i nadal jest ważnym elementem badań dotyczących przemian strukturalnych układów przestrzennych. Skala, dynamika i znaczenie zmian zachodzących na rynkach lokalnych i regionalnych oraz na globalnym rynku pracy jest ogromna. Badania z zakresu geografii społeczno-ekonomicznej, w tym geografii przemysłu i usług, które nie uwzględniałyby aspektu uwarunkowań i problemów rynku pracy, uniemożliwiałyby przeprowadzenie poprawnej analizy i formułowanie wniosków. Geografowie rozumieją tę potrzebę, co ujawniło się w wielu publikacjach naukowych. Celem artykułu jest dokonanie przeglądu prac z zakresu geografii społeczno-ekonomicznej z lat 1945-2013, poświęconych problematyce rynku pracy, ze szczególnym uwzględnieniem ewolucji nurtów badawczych jako konsekwencji przemian polityczno-gospodarczych i społecznych w Polsce oraz analiza zmian paradygmatu w badaniach z zakresu geografii rynku pracy w krajach anglojęzycznych.

\begin{abstract}
The labour market perceived as the mechanisms of its functioning, has been and still is an important part of research devoted to structural changes in various scales of spatial systems. The scale and range of current changes taking place on the local, regional and global labour market is so large that industry and service studies have to take them into consideration. Research in this field, which would not add labour market problems, seems to preclude a proper scientific analysis and formulating conclusions. Geographers have understood this need and it can be seen in several papers. The purpose of the article is to review the scientific papers in the field of socio-economic geography published in the years 1945-2013 which were devoted to labour market problems. The analysis focuses on the evolution of main research streams (as the consequences of political, economic and social changes in Poland) and the change in the paradigm of labour research in geography in Anglophone world (from a geography of labour to a labour geography).
\end{abstract}

Słowa kluczowe: geografia pracy; geografia społeczno-ekonomiczna; kierunki badań; rynek pracy; pracownik

Keywords: employee; geography of labour; labour market; research streams; socio-economic geography; 
Otrzymano: 12 grudnia 2014

Received: 12 December 2014

Zaakceptowano: 5 sierpnia 2015

Accepted: 5 August 2015

\section{Sugerowana cytacja / Suggested citation:}

Piróg, D. (2015). Problematyka pracy $\mathrm{w}$ badaniach $\mathrm{z}$ zakresu geografii społeczno-ekonomicznej w Polsce i krajach anglosaskich. Prace Komisji Geografii Przemystu Polskiego Towarzystwa Geograficznego, 29(4), 127-143.

\section{WSTĘP}

Szeroko pojęty rynek pracy wraz z mechanizmami jego funkcjonowania był i nadal jest ważnym elementem badań dotyczących przemian strukturalnych oraz podsystemów terytorialnego systemu społecznego (Chojnicki, 1988). Pogłębione badania naukowe, realizowane w obrębie geografii społeczno-ekonomicznej, w tym prace z nurtu geografii przemysłu i usług, nie mogą być prowadzone bez zwrócenia należytej uwagi na zagadnienia kapitału ludzkiego i rynku pracy. Bez pracownika, a w szczególności jego kompetencji oraz kwalifikacji, nawet w dobie postępującej mechanizacji i komputeryzacji, niemożliwa byłaby działalność produkcyjna i usługowa, w tym świadczenie usług o wysokim standardzie (Piróg, 2014c).

Kluczowym bodźcem do zainteresowania się geografów zagadnieniami pracy w Polsce była dyskusja nad przedmiotem i metodami badań w geografii społecznej oraz włączenie się do geograficznych prac badawczych specjalistów z zakresu socjologii (Lisowski, 2008). Od początku lat dziewięćdziesiątych XX wieku częstsze podejmowanie problematyki rynku pracy w badaniach geograficznych pozostawało w ścisłym związku z procesami transformacji gospodarczej, globalizacji i integracji ze strukturami unijnymi (Chojnicki, 1999; Fierla, 2011; Maik, 2014; Parysek, 2007; Rogacki, 2007; Stryjakiewicz, 2007; Zioło, 1999).

Choć problematyka rynku pracy, rozumiana jako relacja między podażą a popytem, zagadnienia dotyczące zatrudnienia, mechanizmów oraz konsekwencji bezrobocia, stanowi ważny nurt rozważań specjalistów w wielu dyscyplinach naukowych (głównie ekonomii i socjologii), to geograficzna perspektywa tych badań, wyróżniająca się przestrzennym kontekstem dokonywanych analiz, ma doniosłe znaczenie poznawcze i naukowo-badawcze. Uwzględnienie przestrzennego zróżnicowania cech, dynamiki i kierunków wielorakich przemian na rynkach pracy umożliwia ich pogłębione poznanie, wyjaśnienie oraz formułowanie prognoz w skali lokalnej, regionalnej i globalnej. Geografowie doskonale rozumieli tę potrzebę, co ujawniło się w wielu naukowych publikacjach.

Celem artykułu jest dokonanie:

1) przeglądu polskich publikacji z zakresu geografii społeczno-ekonomicznej z lat 1945-2014 poświęconych problematyce pracownika i rynku pracy, ze szczególnym uwzględnieniem ewolucji nurtów badawczych jako konsekwencji transformacji polityczno-gospodarczej oraz społecznej,

2) analizy zmian paradygmatu w badaniach z zakresu geografii rynku pracy w krajach anglosaskich. 
Tak przegląd dotychczasowych publikacji na temat rynku pracy w naszym kraju, jak i studia literatury zagranicznej, dotyczącej przemian teoretycznych i metodologicznych w podejściu do eksploracji pracy w krajach anglosaskich, są w niniejszym artykule podstawą do próby wskazania dalszych kierunków rozwoju badań geograficznych z tego nurtu tematycznego w Polsce.

Kwerendę polskich opracowań z zakresu geografii społeczno-ekonomicznej sporządzono na podstawie Bibliografii geografii polskiej z lat 1945-2006, zawartości geograficznych czasopism znajdujących się na ministerialnej liście B oraz przeglądu monografii tematycznych. Analizą objęto także wybrane artykuły specjalistów niebędących geografami, które ze względu na ich duże znaczenie w rozwoju geografii społeczno-ekonomicznej były zestawiane (obok prac geografów) w kolejnych tomach Bibliografii geografii polskiej.

Refleksja nad nurtami badawczymi w geografii pracy w krajach anglosaskich została oparta na studiach artykułów opublikowanych w uznanych czasopismach o zasięgu międzynarodowym podejmujących teoretyczne rozważania na ten temat oraz na bazie International Encyclopedia of Human Geography. Wybór krajów anglosaskich wynikał z faktu, że badania geografów dotyczące zagadnień pracy mają tam najdłuższe tradycje, a wypracowane przez nich teoretyczne koncepcje są w środowisku specjalistów zajmujących się problematyką pracy powszechnie uznane za wiodące.

\section{PRACA I RYNEK PRACY W BADANIACH POLSKICH GEOGRAFÓW SPOŁECZNO- -EKONOMICZNYCH}

W badaniach z zakresu geografii społeczno-ekonomicznej szeroko pojęty rynek pracy wraz z problemami jego funkcjonowania cieszył się zmienną (ilościowo i tematycznie) naukową popularnością wśród przedstawicieli tej dyscypliny. W Polsce dział geografii zajmujący się badaniem społeczeństwa, a więc i rynku pracy, ewoluował od geografii handlowej (w połowie XIX wieku) przez antropogeografię (w pierwszej połowie XX wieku), geografię ekonomiczną oraz geografię społeczno-ekonomiczną (w drugiej połowie ubiegłego stulecia), ku geografii społecznej i geografii ekonomicznej (Lisowski, 2008, 2012; Wójcik, Suliborski, 2014).

Jak dowodzi dokonany przegląd literatury, tematyka rynku pracy w badaniach polskich geografów społeczno-ekonomicznych ściśle korelowała z przemianami społecznymi, gospodarczymi oraz politycznymi, zachodzącymi w naszym kraju. Do czasu transformacji geografowie skupiali swoją badawczą uwagę na cechach i dynamice zmian struktur społeczno-zawodowych oraz ruchliwości ludności wynikającej z niezgodności przestrzennego rozmieszczenia zasobów miejsc pracy i pracowników (siły roboczej). Nowe warunki społeczno-ustrojowe w Polsce po roku 1989 uruchomiły szereg procesów społeczno-gospodarczych, a wśród nich powstanie rynku pracy będącego rezultatem podaży i popytu na pracę. Stąd geografowie w swoich badaniach zaczęli podejmować tematykę cech, struktury, dynamiki i nowych procesów tak ukształtowanego rynku pracy w różnych skalach przestrzennych. Do procesów tych należy bezrobocie i ruchliwość społeczna, wynikająca tym razem z uwarunkowań lokalnych i specyfiki krajowego rynku pracy, problemu bezrobocia i dążenia ludności do podniesienia poziomu życia. 
W okresie gospodarki centralnie sterowanej nurtem badawczym cieszącym się największą popularnością była kwestia zasobów pracy oraz powstawania, struktury, funkcjonowania rynków pracy, głównie w przemyśle wydobywczym i przetwórczym, w skali lokalnej, regionalnej i krajowej. Początkowo zajmowano się głównie przemianami struktur społeczno-zawodowych, wynikającymi z industrializacji oraz urbanizacji kraju, w tym zwłaszcza problematyką dwuzawodowości ludności wiejskiej (Dobrowolska, 1963; Dobrowolska, Rajman, 1965) i rolą miejskich rynków pracy w zmianie struktur zatrudnienia w dużych i średnich miastach (Lewiński, 1965). Liczba i struktura zatrudnienia była jedną z podstaw określania wielkości bazy ekonomicznej (Dziewoński, 1967; Jerczyński, 1971). Badano także struktury zawodowe w okręgach lub zakładach przemysłowych jako czynniki rozwoju analizowanych obszarów (Zioło, 1974). W późniejszym czasie zintensyfikowano badania nad zmianami struktury zatrudnienia w poszczególnych sektorach gospodarki w skali lokalnej, regionalnej i krajowej (Frenkel, 1981; Grabowska, 1981; Jędruszczak, 1972). Przemiany te rozpatrywano także z perspektywy wybranych problemów, zwłaszcza stagnacji w zatrudnieniu i rezerw wzrostu zatrudnienia pozarolniczego, typowego dla procesów industrializacji (na przykładach z Anglii) (Józefowicz, 1967) czy koncentracji pracowników wysoko wykwalifikowanych (Rajman, 1972). Potem rosnącym zainteresowaniem zaczęły cieszyć się wybrane zagadnienia zasobów pracy, jak na przykład procesy ich starzenia się (Kotowska, 1990), tematyka siły roboczej w gospodarstwach domowych (Wiatrak, 1990), rozmiary, przyczyny i skutki migracji wysoko wykwalifikowanych kadr z wybranych krajów rozwijających się do krajów rozwiniętych (Liberska, 1977) oraz zmiany zasobów powodowane migracjami zagranicznymi (Dzienio, Drzewieniecka, 1992).

Wspomniana niezgodność przestrzennego rozmieszczenia miejsc pracy i pracowników jako czynnika powodującego konieczność dojazdów do pracy była drugim bardzo istotnym nurtem badawczym w tym okresie. Choć należy podkreślić, że badania dotyczące dojazdów są prowadzone przez geografów do dziś, ewolucji podlegają jedynie cele i metody badawcze. W aspekcie rynku pracy dojazdy były najpierw analizowane jako funkcja popytu na pracę kształtowanego przede wszystkim przez dynamikę i strukturę zapotrzebowania ośrodków lub wybranych zakładów przemysłowych na pracowników, a także przez współzależność oddziaływania struktury miejsc pracy i stosunków społeczno-gospodarczych na terenach wiejskich (Bobek, 1968; Dobrowolska, 1959; Dobrowolska, Rajman, 1964; Herma, 1966; Lijewski, 1967; Jagielski, 1969). Podejmowano badania struktury społeczno-zawodowej jako podstawy do określania skłonności do przesiedleń (Olędzki, 1967). Dojazdy do pracy rozpatrywano z punktu widzenia ich znaczenia dla gospodarki narodowej (Kitowski, 1988), jako wewnętrzną granicę rynku pracy (Runge, 1991). Z kolei w latach dziewięćdziesiątych XX wieku dojazdy do pracy potraktowano jako miernik mobilności siły roboczej (na przykład Bul, 2011, 2013; Churski, 2010; Kaczmarek, Mikuła, 2010), jedną z konsekwencji transformacji gospodarczej (Pakulska, 1994) oraz podstawę do wyznaczania zasięgów lokalnych rynków pracy (Śleszyński, 2012a, 2012b, 2014).

Warunki polityczno-gospodarcze, wynikające z transformacji gospodarki centralnie sterowanej do modelu wolnorynkowego, przyniosły ewolucję rynku pracy w Polsce, który zaczął być kształtowany jako rezultat podaży pracy i popytu na pracę oraz pracowników 
o określonych kompetencjach i kwalifikacjach przebudowującej się gospodarki (Parysek, 1993). Dynamiczna ewolucja rynku pracy indukowała zmiany problematyki badawczej specjalistów zajmujących się tymi wieloaspektowymi procesami. Podjęto się dalszej eksploracji przemian struktur zatrudnienia, ale tym razem z punktu widzenia nasilających się procesów zmian systemu gospodarowania, globalizacji oraz integracji w różnych skalach przestrzennych, na przykład w województwie i aglomeracji poznańskiej (Churski, 1999, 2010; Czyż, Churski, 1993), w Warszawie (Śleszyński, 2007a), w południowo-wschodniej Polsce (Zioło, 1999) czy na Pomorzu Środkowym (Rydz, 1999, 2001, 2006; Szmielińska-Pietraszek, Szymańska, 2009). Dokonano analizy demograficznych uwarunkowań krajowego rynku pracy i wskazano, że niedobory pracowników można traktować jako jedną z barier rozwojowych obszarów, które są silnie uzależnione od wpływu z zewnątrz (Runge, 1990), struktury tradycyjnego rynku pracy (Runge, 1996), przestrzennego, hierarchicznego, strukturalnego i funkcjonalnego wymiaru oraz społeczno-gospodarczych determinant rynku pracy w województwie śląskim (Runge, 1995, 2010). Dokonano również analizy zatrudnienia w usługach (Werwicki, 1992), zatrudnienia w firmach zagranicznych w województwie małopolskim (Domański i in., 2006), a także analizy regionalnego i lokalnych rynków pracy na Dolnym Śląsku (Hasińska, 1993) i rynku pracy na Dolnym Śląsku jako narzędzia do oceny konkurencyjności tego obszaru (Brezdeń, Górecka, Tomczak, 2012). Procesy transformacji gospodarczej były także impulsem do badań poświęconych wpływowi specjalnej strefy ekonomicznej na rynek pracy (na przykładzie SSE Europark Mielec) (Domański, Gwosdz, 2005), zmianom zatrudnienia w działalności rozwojowo-badawczej jako czynnikowi rozwoju gospodarki opartej na wiedzy (Kilar, 2008) czy przestrzennemu funkcjonowaniu systemu edukacji i rynku pracy w relacji z infrastrukturą oraz siecią transportową (Guzik i in., 2013). Prowadzono też badania dotyczące szacowania liczby pracujących $\mathrm{w}$ granicach administracyjnych miasta jako podstawy do analiz rzeczywistego stanu aktywności społeczno-ekonomicznej ludności (Śleszyński, 2010). W ostatnim czasie dokonano także analizy wiejskich rynków pracy w Polsce i rozpatrzono je w aspekcie znaczenia zasobów pracy wsi (Heffner, 2012), problemów kształtowania się rynków pracy na obszarach wiejskich (Ciok, Ilnicki, 2012), a także uwarunkowań demograficznych dla tego rynku w województwie świętokrzyskim (Kamińska, 2012).

Transformacja gospodarcza w Polsce stała się inspiracją do podjęcia badań poświęconych zagadnieniu bezrobocia. To wówczas nowe zjawisko było podstawą do charakterystyki regionalnego zróżnicowania bezrobocia ze względu na jego rozmiary, strukturę, oraz - na podstawie wielocechowych badań prowadzonych z punktu widzenia nowych warunków społeczno-ustrojowych - do typologii krajowego i regionalnych rynków pracy (Gawryszewski, 1993; Parysek, 1993). Bezrobocie rozpatrywano też z punktu widzenia przyczyn (zwłaszcza restrukturyzacji i prywatyzacji) oraz skutków (ekonomicznych i społeczno-psychologicznych) (Dach, 1993) i w powiązaniu z wybranymi cechami gospodarki (Adamczak, Grobelny, 1993; Gołębiewska, 1997; Nowosielska, 1995; Zioło, 1993) w poszczególnych regionach kraju (Jaroszewska, 1993; Kitowski, 1993; Marczyńska-Witczak, 1993), a także z perspektywy regionalnych zmian w jego spadku (Śleszyński, 2007b). 
Zachwianie równowagi między podażą i popytem na rynku pracy było też rozważane przez geografów społecznych jako kluczowa determinanta mobilności pracowników, czyli migracji zagranicznych. Czynnik pracy był rozpatrywany jako element uruchamiający masowe migracje międzykontynentalne, międzynarodowe i wewnątrzkrajowe pracowników (Maryański, 1969), co skutkowało różnorodnymi konsekwencjami tak dla nich samych, jak i dla ogólnej sytuacji na rynku pracy (Rymarczyk, 1986). Zagadnieniem, które zostało w tym nurcie obdarzone szczególnym zainteresowaniem, była sytuacja Polaków jako nielegalnych robotników. W sferze rynku pracy dokonano charakterystyki wizerunku nielegalnego robotnika oraz warunków jego pracy i rozpoznano mechanizm funkcjonowania tego rynku pracy (Mydel, Fassmann, 1997). Prowadzono ponadto badania poświęcone tradycji zarobkowych wyjazdów zagranicznych na Podhalu (Górz, 1994, 2003).

Przedmiotem badań geografów społecznych w całym analizowanym okresie był także rynek pracy intelektualnej i pozycja społeczna pracowników wysoko wykwalifikowanych, czyli absolwentów szkół wyższych. Prowadzono głównie analizy struktury zatrudnienia absolwentów geografii wybranych uczelni (Anioł, Kwiecień, Palmirski, Roja, 1971; Augustyniak, Rajman, Sułek, 1974; Klatka, Zawadzka, 1976; Lisowski, 1999; Piróg, 2006, 2011; Rajman, 1975; Stachowski, 1982; Tracz, Stanuch, 2011). Dokonano diagnozy: destynacji zawodowych geografów w Polsce w skali kraju (Piróg, 2014a; Więckowski, 1978), struktury zatrudnienia absolwentów szkół wyższych z południowo-wschodniej Polski (Rajman, Krakowska, Skwirut, Szczelińska-Kukulak, 1982), relacji między przekształceniami gospodarczymi a rynkiem pracy dla osób z wysokim kapitałem intelektualnym, rozpatrywanej z perspektywy globalnych i krajowych tendencji na rynku pracy intelektualnej (Borowiec, 2008; Gierańczyk, Duży, 2012; Hryniewicz, Jałowiecki, 1994; Piróg, 2013a, 2013b, 2014c). W tym nurcie realizowane były też badania postrzegania atrakcyjności wykształcenia geograficznego na rynku pracy przez studentów geografii w toku studiów (Gierańczyk, Duży, 2011; Piróg 2012a, 2014b) czy poziomu zainteresowania zatrudnieniem w określonej profesji (Piróg, 2012b). Nowym obszarem badawczym relacji studia wyższe - rynek pracy jest specyfika przechodzenia na rynek pracy absolwentów studiów na kierunku geografia, rozpatrywana z punktu widzenia czynników wpływających na jego tempo i charakter oraz przewidywania skutków tego zjawiska (Piróg, 2013c, 2015).

Geografowie społeczno-ekonomiczni wypracowywali nowe metody badawcze, służące jak najpełniejszemu rozpoznawaniu zjawisk zachodzących na rynku pracy. Znalazło to odzwierciedlenie m.in. w publikacjach dotyczących: metody szacowania liczby pracujących w szczegółowej dezagregacji przestrzennej (Śleszyński, 2007a), metody analizy zróżnicowania przewagi konkurencyjnej regionów w zakresie lokalizacji przemysłu, prowadzonej w oparciu o relacje wydajności do kosztów pracy (Rachwał, Wiedermann, Kilar, 2008), tzw. dwuetapowych metod badań dojazdów do pracy (Wiśniewski, 2012) czy zmodyfikowanej metody pól semantycznych do badań poświęconych procesowi przechodzenia absolwentów studiów geograficznych na rynek pracy (Piróg, 2014d).

Podsumowując tę część rozważań, należy stwierdzić, że tematyka rynku pracy w badaniach polskich geografów społeczno-ekonomicznych dotychczas obejmowała trzy główne nurty badawcze. Po pierwsze, zajmowano się przemianami struktur społeczno-zawodowych 
pracowników jako skutku postępujących procesów industrializacji, urbanizacji oraz transformacji gospodarczej. Po drugie, dokonywano analiz przestrzennego zróżnicowania zasobów pracy i ruchliwości ludności wynikającej z uwarunkowań lokalnych i specyfiki krajowego rynku pracy. Po trzecie, zgłębiano różnorodne problemy (w ujęciu przyczyno-skutkowym) pojawiające się na rynku pracy, szczególnie zjawisko bezrobocia. Wszystkie wymienione obszary badawcze były podstawą do pogłębionych analiz rynku pracy w różnych skalach jego funkcjonowania (krajowej, lokalnej lub regionalnej). Publikacje odzwierciedlają tak podejście analityczne, opisowe, jak i syntetyczne - wyjaśniające. W całym rozpatrywanym okresie w opracowaniach ujawnia się wyraźna przewaga orientacji scjentystycznej i radykalnej.

\section{ZMIANA PARADYGMATU W BADANIACH Z ZAKRESU GEOGRAFII RYNKU PRACY W KRAJACH ANGLOSASKICH}

Problematyka pracy w geografii anglosaskiej ma długie tradycje, sięgające początku XX wieku. Najpierw badania dotyczyły przede wszystkim wpływu związków zawodowych (ang. geographies of trade unionism) na strukturę i wielkość wydobycia poszczególnych surowców, produkcję przemysłową oraz handel. Skupienie badawczej uwagi geografów na tych kwestiach wynikało z faktu, że związki zawodowe intensywnie współdecydowały o profilu i charakterze funkcjonowania przedsiębiorstw, tworzeniu nowych miejsc pracy (zwłaszcza w przemyśle), nie tylko w skali lokalnej, ale i ponadregionalnej. Odbywało się to głównie przez oddziaływanie związków na rozwój technologiczny, np. dążyły one do spowalniania modernizacji produkcji po to, aby chronić miejsca pracy, a tym samym kształtowały tempo i kierunek przemian w rozwoju przemysłu. Zmiany w gospodarce, polegające na zakończeniu dominacji przemysłu surowcowego, przywiązanego do miejsca, i rozwoju przemysłu przetwórczego oraz wysokiej technologii, ograniczyły rolę związków we współkreowaniu struktury produkcji przemysłowej. Z czasem geografowie zaczęli ich rolę rozpatrywać głównie z punktu widzenia działań na rzecz pracowników (ochrony ich praw, warunków pracy) (Rutherford, 2009).

Znacząca intensyfikacja badań geograficznych poświęconych zagadnieniom pracy i podjęcie nowych problemów badawczych nastąpiło na początku lat osiemdziesiątych $\mathrm{XX}$ wieku. Bodźcem do natężonego zainteresowania geografów zagadnieniami pracy oraz dyskusji nad orientacją badawczą były studia socjologów, skupiające się na roli klasy pracującej (z punktu widzenia jej składu oraz struktury) w zmianie społecznej, i ustalenia dokonane przez Doreen Massey w 1984 roku, traktujące o przestrzennym podziale pracy (Castree, 2007). Geografowie ekonomiczni zaczęli wówczas prowadzić intensywne badania dotyczące wpływu rozmieszczenia zasobów siły roboczej na zróżnicowanie rozwoju regionów, zwłaszcza ich potencjału produkcyjnego w różnej skali układów przestrzennych. Badania były oparte na założeniu, że na pracę należy patrzeć jako na bardzo istotny czynnik rozwoju przemysłu, czyli czynnik kosztów, kontroli i reprodukcji siły roboczej. 
Wartość naukowa publikacji geografów na temat pracy, stworzona przez nich koncepcja i metody badawcze służące poznawaniu procesów zachodzących na rynku pracy oraz świadomość głębokich zmian w tym obszarze życia gospodarczo-społecznego, nasilających się pod wpływem postępu technicznego, spowodowała, że w tym czasie z geografii ekonomicznej wyodrębniono geografię pracy jako osobną subdyscyplinę naukową (ang. geography of labor) (Rutherford, 2009). Przyjęta w tej subdyscyplinie radykalna orientacja badawcza oraz strukturalno-funkcjonalne spojrzenie na rynek pracy były naturalną konsekwencją tradycji badawczych geografów ekonomicznych, z których wyrośli geografowie pracy. Tak jak geografowie ekonomiczni traktowali wtedy pracowników z punktu widzenia kosztów, a nie jako podmioty lub członków grupy, tak geografowie pracy - w analogii do takiego podejścia za aksjomat przyjęli, że przestrzenne zróżnicowanie zapotrzebowania na określone zasoby pracy determinuje ich skład i struktury. Kluczowymi problemami badawczymi geografów pracy uczyniono głównie zmiany pionowe (struktury płci, wieku, struktury zawodowe, stanu cywilnego) i poziome (ruchy migracyjne), rozpatrywane przede wszystkim jako odpowiedź na zróżnicowane przestrzennie potrzeby rynku pracy. Takie podejście w badaniach z zakresu geografii pracy było powszechne do końca lat dziewięćdziesiątych XX wieku (Castree, 2007). Należy jednak stwierdzić, że miało ono zarówno zwolenników, jak i oponentów. Ci drudzy uważali, że nie tylko przestrzeń oddziałuje na ludzi/pracowników, powodując ich zmiany (strukturalne) czy indukując kierunki oraz stopień mobilności, ale że sami ludzie są ważnymi ,,aktorami na scenie” w tej przestrzeni i zmieniają ją nie tylko w przyjmowanym dotychczas kontekście negatywnego wpływu na stan środowiska. W zakresie pracy ludzie/pracownicy mogą znacząco oddziaływać na strukturę, jakość produkcji przemysłowej i usług. To pojedynczy człowiek mający wolną wolę, a nie upodmiotowiona siła robocza czy kapitał ludzki, decyduje o tym, jaką pracę chce wykonywać i jak ją wykona. Przy tym założeniu procesy zachodzące na rynku pracy, przemiany strukturalne oraz funkcjonalne w gospodarce i społeczeństwie nie mogą być badane jedynie jako funkcja popytowo-podażowa. Te kwestie dostrzegł i wyraził Andrew Herod, publikując w 1997 roku w prestiżowym czasopiśmie „Anitpode” artykuł pt. From a geography of labor to a labor geography: labor's spatial fix and the geography of capitalism (Herod, 1997).

Herod stwierdził, że dominujące dotychczas ujęcie strukturalno-funkcjonalne i unikanie traktowania pracowników jako aktywnych kreatorów przestrzeni ${ }^{1}$ nie nadąża za przemianami współczesnego świata i nie wystarcza do prowadzenia nowoczesnych badań geograficznych w zmieniających się warunkach. Opowiedział się za skupieniem uwagi geografów zajmujących się teoretycznymi koncepcjami rozwoju regionalnego na pracownikach. Jego zdaniem biologiczne i socjologiczne cechy pracownika są ważnym deskryptorem regionu/ miejsca, określają perspektywy rozwoju oraz kierunki zmian tak samego pracownika, jak i regionu, w którym on funkcjonuje. Herod zakłada, że pomimo nasilających się problemów na rynku pracy, zwłaszcza nadwyżki pracowników, człowiek coraz częściej będzie sam wybierał sobie pracę zgodną z jego filozofią życia. To, na jaką pracę się zdecyduje, jak będzie ją wykonywał, formować będzie jego życie, poziom satysfakcji i zaangażowanie w rozwój

${ }^{1}$ „Economic geographies devoid of workers as active geographical agents” (Herod, 1997: 2). 
regionu. Takie spojrzenie na relację człowiek-praca-przestrzeń kończyło w badaniach czas majoryzowania, a niekiedy wręcz deterministycznego założenia o wpływie przestrzeni na ludzi (jako całości) i ich działalność. Przedmiotowe patrzenie na ludzi i pracę jako na siłę roboczą, zasoby pracy, podaż pracy i kapitał ludzki zamieniono na ujęcie podmiotowe, czyli pracownika, indywiduum, jednostkę, człowieka. Rozpoczęło to ewolucję w badaniach geografii pracy w kierunku analizy i refleksji nad przestrzenią antycypowaną przez pryzmat człowieka/pracownika o określonych cechach istotnych z punktu widzenia rozwoju regionu. W rezultacie A. Herod postulował zmianę nazwy subdyscypliny z geograhpy of labor na labor geography (z ,geografia pracy” na „praca w geografii”), w której zaczęło dominować personalistyczne ujęcie filozoficzno-ideologiczne (Herod, 1997).

Tab. 1. Dekonstrukcja paradygmatu geograghy of labor na labor geography

\begin{tabular}{|c|c|}
\hline Geography of labor & Labor geography \\
\hline \multicolumn{2}{|c|}{ orientacja } \\
\hline - neoklasycystyczna & - behawioralna i instytucjonalna \\
\hline \multicolumn{2}{|c|}{ ujęcie } \\
\hline - strukturalno-funkcjonalne & - filozoficzno-ideologiczne \\
\hline \multicolumn{2}{|c|}{ człowiek } \\
\hline $\begin{array}{l}\text { - } \text { siła robocza jako czynnik (np. lokalizacji } \\
\text { przemysłu) } \\
\text { - zasoby ludzkie } \\
\text { - kapitał ludzki }\end{array}$ & $\begin{array}{l}\text { - pracownik (o określonych cechach) } \\
\text { - indywiduum; podmiot (płeć, rasa, } \\
\text { narodowość) } \\
\text { - kreator rozwoju społeczno-gospodarczego } \\
\text { regionu }\end{array}$ \\
\hline \multicolumn{2}{|c|}{ wiodące nurty } \\
\hline $\begin{array}{l}\text { - związki zawodowe } \\
\text { - teorie lokalizacji } \\
\text { - struktury zawodowe }\end{array}$ & $\begin{aligned} & \text { - } \text { nowe formy organizacji pracy } \\
& \text { - } \text { korporacje ponadnarodowe } \\
& \text { (internacjonalizacja pracy) } \\
& \text { - } \text { mikrogeografia pracy } \\
& \text { - ścieżki przemian }\end{aligned}$ \\
\hline
\end{tabular}

Źródło: opracowanie własne na podstawie: Herod (1997), Castree (2007)

Przyjęcie nowego paradygmatu dopuszczało eklektyzm i interdyscyplinarność, a nawet ich wymagało, zarówno w zakresie tematyki, jak i metod badawczych. Spowodowało to, że od lat dziewięćdziesiątych XX wieku w krajach anglosaskich ta naukowa dyscyplina rozwijała się bardzo dynamicznie. Najpierw znacznym zainteresowaniem zaczęły się cieszyć kwestie ewolucji hierarchii społecznych, analizowane przez pryzmat przedstawicieli danej płci, rasy, narodowości, postępujące wraz ze zmianami zachodzącymi na tradycyjnym rynku i ich oddziaływaniem na pozycję danego regionu (w porównaniu z innymi). Potem do kluczowych tematów badań dołączyły nowe formy organizacji pracy i ich wpływ na zmianę modelu życia zawodowego człowieka. Na przełomie wieków obszary zainteresowania przesuwały się w stronę zagadnień związanych z procesami globalizacji i internacjonalizacji pracy. Geografowie pracy koncentrowali też badawczą uwagę na tym, jak i na ile nowe formy pracy (np. praca online), rozwój branży IT czy lawinowy postęp technologiczny przekształcają lub 
tworzą nowe typy relacji społecznych. Nowy paradygmat badań skutkował też przemianami w analizach międzynarodowych korporacji, które wcześniej były prowadzone z perspektywy ich oddziaływania na rozwój regionu, a potem dotyczyły przede wszystkim kwestii różnicowania charakterystyk pracowników i ich funkcjonowania w środowisku pracy i życiu społecznym. Obecnie coraz częściej badania z zakresu geografii pracy są prowadzone w ścisłym związku z tematyką z zakresu geografii potrzeb i jakości życia. Analizy dotyczą przestrzennego zróżnicowania stopnia zaspokajania potrzeby dostępu do pracy, warunków pracy w kontekście aspiracji i zadowolenia w mniej uprzywilejowanych - ze względu na rasę, płeć, narodowość - strukturach społecznych (Rutherford, 2009).

\section{DALSZE KIERUNKI ROZWOJU I BADAŃ}

Rynek pracy należy do jednego z najbardziej dynamicznych obszarów życia społeczno-gospodarczego, co stwarza nowe potrzeby i możliwości w zakresie pól oraz ujęć badawczych stosowanych w geografii pracy. Obecnie, w toku teoretyczno-metodologicznych dyskusji naukowych poświęconych dalszym kierunkom i metodom badań, zakłada się, że osią postępowania badawczego geografowie pracy powinni czynić pracownika i poprzez ilościowo-jakościowe analizy specyfiki pracy człowieka oraz jego stosunku do tej sfery swojej działalności zmierzać do poznania współczesnej relacji człowiek-świat. Jak ujmuje to Noel Castree: „Geografowie pracy za często osadzają pracujących w centrum analizy i wtedy badania donoszą o warunkach pracy danej osoby, grupy osób oraz separują się tak analitycznie, jak i ontologicznie od szerszego oglądu. Wskazane jest badanie pracowników nie tylko z punktu widzenia zatrudnienia, ale jako okna do patrzenia na to, jak ludzie żyją i chcą żyć” (Castree, 2007: 856).

$\mathrm{Na}$ świecie do najważniejszych problemów badawczych, które są lub powinny być naukowo rozpoznawane w tym duchu, zalicza się:

1) Mechanizmy (zmian), którym podlega lub które indukuje pracownik na rynku pracy w określonej przestrzeni. Potrzebne jest wieloaspektowe poznanie ponadnarodowej organizacji pracy jako czynnika kreującego nowe formy życia społecznego, modele kariery zawodowej człowieka i specyficzne struktury oraz relacje społeczne, powodujące zróżnicowanie przestrzenne. Bardzo istotne jest badanie oddziaływania związków zawodowych versus działania ruchów społecznych jako przejawu ewolucji roli pracownika w kształtowaniu życia gospodarczego i funkcjonowania społeczeństwa. Wskazuje się na potrzebę badań z tzw. mikrogeografii pracy, czyli pogłębionej analizy specyfiki funkcjonowania pracownika w pojedynczym przedsiębiorstwie, z punktu widzenia jego rozwoju osobistego i udziału w kreowaniu pozycji firmy w kontekście rozwoju regionalnego. Wreszcie na uwagę zasługują mechanizmy zmian (tzw. ścieżki przemian) w człowieku (jego stylu życia, modelu rodziny itp.) wynikające z pracy, którą wykonuje, i ścieżki kariery zawodowej, jaką realizuje, ze szczególnym podkreśleniem tych przemian wg płci, rasy, wieku i narodowości.

2) Problemy pracownika wynikające z sytuacji na rynku pracy. Nadal bardzo ważne jest badanie bezrobocia, ale nie z punktu widzenia diagnozy, dynamiki, przyczyn, skutków i dalszych kierunków (choć także w pewnym stopniu), ale jako próby wskazania nowych 
obszarów zarobkowania człowieka i współczesnych czynników zachęcających do mobilności pracowników w warunkach dalszego globalnego spadku miejsc pracy oraz postępu technologicznego. Szczególnie oczekiwane są opracowania podejmujące ten problem w skali ponadregionalnej i globalnej. Wzrasta potrzeba badań nad wpływem migrantów (zarobkowych) na kształtowanie się nowych struktur społecznych i zawodowych. Migracje te powinno się traktować zarówno jako cel poznania w kontekście przemian społeczno-kulturowych i gospodarczych, które mogą one indukować, jak i jako sposób wyznaczania czy charakterystyki chłonnych oraz nasyconych rynków pracy.

3) Badania teoretyczno-porządkujące, zmierzające do syntezy dotychczasowej wiedzy na temat:

- metod i wyników badań poświęconych współczesnym relacjom pomiędzy: pracownikami, pracownikami a pracodawcami (rynkiem pracy), pracodawcami (przedsiębiorstwami) oraz ustalenia mechanizmów nimi kierujących,

- aktualnych i prognozowanych kierunków przemian społeczno-gospodarczych, będących konsekwencją tych mechanizmów w różnej skali (mikro, mezo, makro) (Castree, 2007; Rutherford, 2009).

Jak wskazują studia literatury przedmiotu, w Polsce kwestie rynku pracy oraz pracownika cieszą się obecnie bardzo dużym zainteresowaniem wśród ekonomistów i socjologów, mniejszym zaś pośród geografów. Dalsze kierunki rozwoju badań w geografii pracy, wskazywane w krajach anglosaskich, wydają się być dobrą podstawą do namysłu nad tym, które problemy odnoszące się do zagadnień pracy i pracownika powinny być podejmowane w naszym kraju właśnie przez geografów oraz jakie koncepcje badawcze sprzyjają nowoczesnemu ujęciu tych kwestii w ich badaniach naukowych. Wydaje się, że ujęcie skupione na przestrzennej analizie rynku pracy, prowadzonej z punktu widzenia pracujących, bezrobotnych, struktur zatrudnienia, które wynika głównie z: tradycji badawczych, zawartości dostępnych źródeł informacji statystycznych, bardzo dużej kosztochłonności i trudności w pozyskiwaniu danych własnych, może być niewystarczające do tego, by badania prowadzone przez geografów w tym zakresie miały w przyszłości najwyższą wartość naukową oraz aplikacyjną. Rodzi się potrzeba pilnej dyskusji nad koncepcją geograficznych badań rynku pracy, która byłaby zarówno konkurencyjna, jak i komplementarna w stosunku do opracowań z innych dyscyplin naukowych. Sprzyja temu obecnie kilka czynników. Po pierwsze, ustalenia dotyczące koncepcji badawczych w innych krajach, zamieszczone m.in. w niniejszej pracy. Po drugie, postpozytywistyczny paradygmat w geografii społeczno-ekonomicznej, który stwarza możliwości stosowania różnych modeli postępowania badawczego (od ujęcia matematyczno-modelowego po humanistyczne). Po trzecie, przebudowa problemowa tak w geografii społecznej, jak i ekonomicznej, wynikająca z procesów transformacji, integracji oraz globalizacji. Wreszcie, po czwarte, przemiany metodologiczne, które zachodzą w polskiej geografii społeczno-ekonomicznej z ujęcia strukturalno-funkcjonalnego, dominującego w latach sześćdziesiątych i siedemdziesiątych XX wieku, ku rozwiązaniom filozoficznym i ideologicznym (Maik, 2014), są dobrą bazą do podjęcia próby określenia dalszych kierunków i metod badań rynku pracy przez geografów w Polsce. 


\section{Literatura \\ References}

Adamczak, Z., Grobelny, R. (1993). Wybrane makroekonomiczne uwarunkowania bezrobocia w Polsce na początku lat dziewięćdziesiątych. Biuletyn Komitetu Przestrzennego Zagospodarowania Kraju $P A N, 161,31-40$.

Anioł, C., Kwiecień, S., Palmirski, J., Soja, R. (1971). Kierunki zatrudnienia absolwentów UJ z lat 1954-1965. Zeszyty Naukowe Uniwersytetu Jagiellońskiego, 149, Prace Geograficzne, 27, Prace Instytutu Geografii UJ, 49, 7-15.

Augustyniak, B., Rajman, L., Sułek, M. (1974). Główne kierunki zatrudnienia absolwentów geografii Uniwersytetu Jagiellońskiego z lat 1966-1971. Zeszyty Naukowe Uniwersytetu Jagiellońskiego, $38,163-177$.

Bobek, Z. (1968). Dojazdy do pracy w okręgu siarkowo-metalurgicznym. Demograficzno-osadnicze problemy w Tarnobrzeskim Rejonie Uprzemysłowionym. Zeszyty Badań Rejonów Uprzemystawianych PAN, 29, 177-197.

Borowiec, M. (2008). Kształcenie na poziomie akademickim jako czynnik przygotowania kadr dla przemysłu województwa podkarpackiego. Prace Komisji Geografii Przemysłu Polskiego Towarzystwa Geograficznego, 10, 245-266.

Brezdeń, P., Górecka, S., Tomczak, P. (2012). Edukacja i rynek pracy Dolnego Śląska na tle uwarunkowań demograficznych. Rozprawy Naukowe Instytutu Geografii i Rozwoju Regionalnego Uniwersytetu Wrockawskiego, 22.

Bul, R. (2011). Dojazdy ludności do pracy w Poznańskim Obszarze Metropolitalnym. Transport Miejski i Regionalny, 718, 31-38.

Bul, R. (2103). Migracje wahadlowe mieszkańców aglomeracji poznanskiej w okresie intensywnej suburbanizacji. Rozprawa doktorska.

Castree, N. (2007). Labor geography: a work in progress. International Journal of Urban and Regional Research, 31(4), 853-862. DOI:10.1111/j.1468-2427.2007.00761.x

Chojnicki, Z. (1988). Terytorialny system społeczny. Biuletyn Komitetu Przestrzennego Zagospodarowania Kraju PAN, 138, 29-49.

Chojnicki, Z. (1999). Podstawy metodologiczne i teoretyczne geografii. Poznań: Bogucki Wydawnictwo Naukowe.

Churski, P. (1999). Lokalne rynki pracy w województwie poznańskim w okresie transformacji spoleczno-gospodarczej. Poznań: Bogucki Wydawnictwo Naukowe.

Churski, P. (red.) (2010). Rynek pracy i mobilność sity roboczej w aglomeracji poznańskiej. Biblioteka Aglomeracji Poznańskiej, 5. Poznań: Bogucki Wydawnictwo Naukowe.

Ciok, S., Ilnicki, D. (2012). Demograficzne i przestrzenne uwarunkowania rynku pracy na wsi dolnośląskiej. W: W. Kamińska, K. Heffner (red.). Wiejskie rynki pracy-zasoby, aktywizacja, nowe struktury. Studia Komitetu Przestrzennego Zagospodarowania Kraju PAN, CXLV, 142-162.

Czyż, T., Churski, P. (1993). Struktura społeczno-gospodarcza a kształtowanie się bezrobocia w województwie poznańskim. W: W. Maik (red.). Problematyka lokalnych systemów osadniczych. Poznań: Wydawnictwo Uniwersytetu Adama Mickiewicza, 63-75.

Dach, Z. (1993). Bezrobocie w okresie przemian systemowych gospodarki polskiej. Prace Komisji Nauk Ekonomicznych, 16, Wrocław: Zakład Narodowy im. Ossolińskich.

Dobrowolska, M. (1959). Dojazdy do pracy i struktura zatrudnienia w województwie krakowskim. Praca wykonana na zlecenie Rady Naukowo-Ekonomicznej przy Wojewódzkim Komitecie Planowania Gospodarczego w Krakowie (maszynopis w archiwum WKPG w Krakowie).

Dobrowolska, M. (1963). Studia nad zagadnieniem chłoporobotników w Polsce Południowej. Wieś Współczesna, 7(1), 52-61.

Dobrowolska, M., Rajman, J. (1964). Dojazdy do pracy w województwie opolskim. Materiały i Studia Opolskie, 10, 5-36. 
Dobrowolska, M., Rajman J. (1965). Socio-economic structure and dynamics of the suburban zone. Geographia Polonica, 7, 115-132.

Domański B., Gwosdz, K. (red.) (2005). Dziesięć lat doświadczeń pierwszej polskiej specjalnej strefy ekonomicznej. Mielec 1995-2005, Kraków-Mielec: Instytut Geografii i Gospodarki Przestrzennej Uniwersytetu Jagiellońskiego, Agencja Rozwoju Przemysłu oddział w Mielcu.

Domański, B., Gwosdz, K., Działek, J., Huculak, M., Janas, K., Jarczewski, W., Micek, G., Sobala-Gwosdz, A. (2006). Inwestycje zagraniczne w Małopolsce 1989-2005. Kraków: Urząd Marszałkowski.

Dzienio, K., Drzewieniecka, K. (1992). Zmiany zasobów pracy a migracje zagraniczne w latach 19902010. Gospodarka Narodowa, 7/8, 28-35.

Dziewoński, E. (1967). Baza ekonomiczna i struktura funkcjonalna miast. Studium rozwoju pojęć, metod i ich zastosowań. Prace Geograficzne, 63, Warszawa: Instytut Geofizyki PAN.

Fierla, I. (red.) (2011). Polska w Europie. Zarys geograficzno-ekonomiczny. Warszawa: Polskie Wydawnictwa Ekonomiczne.

Frenkel, I. (1981). Zmiany zatrudnienia w rolnictwie polskim. Wieś Współczesna, 11, 43-52.

Gawryszewski, A. (1993). Struktura przestrzenna zatrudnienia i bezrobocia w Polsce 1990-1992. Warszawa: Instytut Geografii i Przestrzennego Zagospodarowania PAN, 13.

Gierańczyk, W., Duży, W. (2011). Zawód geograf - atrakcyjność studiów geograficznych a przydatność na rynku pracy (w opiniach studentów kierunku geografia na Wydziale Biologii i Nauk o Ziemi Uniwersytetu Mikołaja Kopernika). Prace Komisji Edukacji Geograficznej Polskiego Towarzystwa Geograficznego, 2, 113-134.

Gierańczyk, W., Duży, W. (2012). Absolwenci kujawsko-pomorskich szkół wyższych - kadry dla regionalnej gospodarki? Studia i Analizy Europejskie, 2(10), 125-135.

Gołębiewska, T. (1997). Problemy bezrobocia i aktywności zawodowej ludności. Przegląd Geograficzny, 69(1/2), 55-75.

Górz, B. (1994). Emigracja zarobkowa ludności wsi podhalańskich do Stanów Zjednoczonych Ameryki Północnej. W: B. Górz (red.). Studia nad przemianami Podhala. Prace Monograficzne, 172. Kraków: Wydawnictwo Naukowe Wyższej Szkoły Pedagogicznej w Krakowie, 92-117.

Górz, B. (2003). Spoteczeństwo i gospodarka Podhala w okresie transformacji. Prace Monograficzne, 359. Kraków: Wydawnictwo Naukowe Akademii Pedagogicznej im. Komisji Edukacji Narodowej.

Grabowska, U. (1981). Społeczno-zawodowa struktura ludności we wsiach podmiejskich. Wieś Wspótczesna, 11, 119-125.

Guzik, R., Wiedermann, K., Antończak, K., Chrześcijanek, A., Guzik, E., Węgrzyn, M. (2013). Zawodowy start. Przestrzenne uwarunkowania karier i dalszych losów absolwentów. Kraków: Wydawnictwo Uniwersytetu Pedagogicznego.

Hasińska, Z. (1993). Regionalne i lokalne rynki pracy na Dolnym Śląsku, Wrocław: Wydawnictwo Akademii Ekonomicznej.

Heffner, K. (2012). Wiejskie rynki pracy w Polsce - kurczące się zasoby czy niewyczerpane rezerwy? W: W. Kamińska, K. Heffner (red.). Wiejskie rynki pracy - zasoby, aktywizacja, nowe struktury. Studia Komisji Przestrzennego Zagospodarowania Kraju PAN, CXLV, 8-51.

Herma, J. (1966). Dojazdy do pracy w Polsce południowej. Prace Monograficzne, V. Kraków: Wyższa Szkoła Pedagogiczna.

Herod, A. (1997). From a geography of labor to a labor geography: labor's spatial fix and the geography of capitalism. Antipode, 29(1), 1-33. DOI 10.1111/1467-8330.00033

Hryniewicz, J., Jałowiecki, B. (1994). Rynek pracy intelektualnej w Polsce. Europejski Instytut Rozwoju Regionalnego i Lokalnego. Studia Regionalne i Lokalne, 13.

Jagielski, A. (1969). Niektóre przestrzenne aspekty dojazdów do pracy. Przegląd Geograficzny, 41(4), 651-672. 
Jaroszewska, R. (1993). Zmiany na rynku pracy w Toruniu w latach 1990-1991. Biuletyn Komitetu Przestrzennego Zagospodarowania Kraju PAN, 161, 95-110.

Jerczyński, M. (1971). Metody pośrednie identyfikacji i pomiaru bazy ekonomicznej miast. Prace Geograficzne Instytutu Geografii PAN, 87, 111-141.

Jędruszczak, H. (1972). Zatrudnienie a przemiany społeczne w Polsce w latach 1944-1960. Wrocław: Zakład Narodowy im. Ossolińskich.

Józefowicz, A. (1967). Zagadnienie stagnacji w zatrudnieniu. Warszawa: Polskie Wydawnictwa Ekonomiczne.

Kaczmarek, U., Mikuła, Ł. (2010). Mobilność siły roboczej na rynku pracy aglomeracji poznańskiej. W: P. Churski (red.). Rynek pracy i mobilność sity roboczej w aglomeracji poznańskiej. Poznań: Bogucki Wydawnictwo Naukowe, 131-150.

Kamińska, W. (2012). Wiejski rynek pracy w województwie świętokrzyskim na tle uwarunkowań demograficznych. W: W. Kamińska, K. Heffner (red.). Wiejskie rynki pracy-zasoby, aktywizacja, nowe struktury. Studia Komitetu Przestrzennego Zagospodarowania Kraju PAN, CXLV, 229-255.

Kilar, W. (2008). Zatrudnienie w działalności badawczej i rozwojowej jako czynnik rozwoju gospodarki opartej na wiedzy. Przedsiębiorczość-Edukacja, 4, 60-69.

Kitowski, J. (1988). Rola dojazdów do pracy w gospodarce narodowej. Lublin: Wydawnictwo Uniwersytetu Marii Curie-Skłodowskiej.

Kitowski, J. (1993). Analiza rynku pracy w Rzeszowie w latach 1981-1991. Biuletyn Komitetu Przestrzennego Zagospodarowania Kraju PAN, 161, 81-94.

Klatka, T., Zawadzka, A. (1976). Struktura zatrudnienia geografów a plany studiów. Acta Universitatis Lodziensis, II, 4, 121-133.

Kotowska, I. (1990). Starzenie się zasobów pracy w Polsce. Studia Demograficzne, 3, 41-62.

Lewiński, S. (1965). Zmiany struktur zatrudnienia na przykładzie dużych i średnich miast polskich. Warszawa: Instytut Urbanistyki i Architektury, 106.

Liberska, B. (1977). Migracja kadr wysoko kwalifikowanych z krajów rozwijających się: (drenaż mózgów). Warszawa: Państwowe Wydawnictwo Naukowe.

Lijewski, T. (1967). Dojazdy do pracy w Polsce. Studia Komitetu Przestrzennego Zagospodarowania Kraju PAN, 15.

Lisowski, A. (1999). Zatrudnienie absolwentów geografii Uniwersytetu Warszawskiego w latach dziewiećdziesiątych. W: A. Lisowski (red.). Geografia na przełomie wieków - jedność w różnorodności. Warszawa: Wydawnictwa Uniwersytetu Warszawskiego, 264-273.

Lisowski, A. (2008). Geografia społeczna. W: A. Jackowski, S. Liszewski, A. Rychling (red.). Historia geografii polskiej. Warszawa: Wydawnictwo Naukowe PWN, 195-205.

Lisowski, A. (2012). O miejscu geografii społeczno-ekonomicznej w geografii i systemie nauki. Przeglad Geograficzny, 84(2), 171-198.

Maik, W. (2014). Refleksje dotyczące rozwoju geografii społeczno-ekonomicznej. Komentarz po trzydziestu latach od konferencji w Rydzynie. W: W. Maik, K. Rembowska, A. Suliborski (red.). Dorobek polskiej geografii po konferencji w Rydzynie. Ocena krytyczna. Łódź: Wydawnictwo Uniwersytetu Łódzkiego, 219-242.

Marczyńska-Witczak, E. (1993). Przestrzenne aspekty łódzkiego rynku pracy. Biuletyn Komitetu Przestrzennego Zagospodarowania Kraju PAN, 161, 63-80.

Maryański, A. (1969). Współczesne wędrówki zarobkowe. Nauka dla Wszystkich, 87, Kraków: Wydawnictwo PAN.

Mydel, R., Fassmann, H. (1997). Nielegalni robotnicy cudzoziemscy i czarny rynek pracy. Polscy nielegalni pracownicy w Wiedniu. Kraków: Wydawnictwo Uniwersytetu Jagiellońskiego.

Nowosielska, E. (1995). Bezrobocie - przegląd aktualnych tendencji, problemów i wyniki badań (w krajach rozwiniętych). Zeszyty Instytutu Geografii i Przestrzennego Zagospodarowania PAN, 35.

Olędzki, M. (1967). Dojazdy do pracy. Zagadnienia społeczne i ekonomiczne na przykładzie rejonu płockiego. Komitet Badań Rejonów Uprzemysławianych PAN. Warszawa: Książka i Wiedza. 
Pakulska, T. (1994). Dojazdy do pracy ludności wiejskiej w nowych warunkach społeczno-ekonomicznych kraju. Biuletyn Instytutu Gospodarstwa Społecznego, 37(3/4), 89-113.

Parysek, J. (1993). Regionalne zróżnicowanie rynków pracy w Polsce na początku lat dziewięćdziesiątych. Biuletyn Komitetu Przestrzennego Zagospodarowania Kraju PAN, 161, 7-30.

Parysek, J. (2007). Społeczeństwo. W: H. Rogacki (red.). Geografia społeczno-gospodarcza Polski. Warszawa: Wydawnictwo Naukowe PWN, 91-164.

Piróg, D. (2006). Absolwenci nauczycielskich studiów geograficznych na krakowskim rynku pracy. Dokumentacja geograficzna, 33. Warszawa: Instytut Geografii i Przestrzennego Zagospodarowania PAN, 338-345.

Piróg, D. (2011). Graduates of geographical studies on the labour market in the process of transformation in higher education. Prace i Studia Geograficzne, 48, Prace Instytutu Geografii Uniwersytetu Jana Kochanowskiego, 18, 161-172.

Piróg, D. (2012a). Aspiracje i plany zawodowe młodzieży akademickiej w Polsce na przykładzie studentów geografii. W: A. Dudak, K. Klimkowska, A. Różański (red.). Przygotowanie zawodowe młodych pedagogów. Kraków: Oficyna Wydawnicza Impuls, 125-144.

Piróg, D. (2012b). Poziom zainteresowania pracą w zawodzie nauczyciela wśród studentów geografii. Prace Komisji Edukacji Geograficznej Polskiego Towarzystwa Geograficznego, 2, 194-210.

Piróg, D. (2013a). Absolwenci szkół wyższych na rynku pracy w warunkach kryzysu. Przedsiębiorczość w warunkach kryzysu. Przedsiębiorczość-Edukacja, 9, 302-316.

Piróg, D. (2013b). Poszukiwanie pracy przez absolwentów studiów geograficznych w okresie tranzycji. Polityka Społeczna, 5-6, 8-14.

Piróg, D. (2013c). Wybrane determinanty tranzycji absolwentów studiów wyższych na rynek pracy. Dylematy współczesnego rynku pracy. Studia Ekonomiczne. Zeszyty Naukowe Wydziałowe Uniwersytetu Ekonomicznego w Katowicach, 160, 131-138.

Piróg, D. (2014a). Destinations of geography graduates on the labour market in Poland and other countries. Geographia Polonica, 87(1). 95-112.

Piróg, D. (2014b). Do geography studies facilitate a smooth transition to the job market? Reflections of working and jobseeking graduates. Journal of Geography in Higher Education, 38(2), 155-174. DOI:10.1080/03098265.2014.901301

Piróg, D. (2014c). The impact of degree programme educational capital on the transition of graduates to the labour market. Studies in Higher Education, 1-15. DOI: 10.1080/03075079.2014.914916

Piróg, D. (2014d). W poszukiwaniu metodologicznych innowacji w badaniach jakościowych - przykład z analiz przechodzenia absolwentów geografii na rynek pracy. Annales Universitatis Paedagogicae Cracoviensis Studia Geographica, VI, 162, 9-19.

Piróg, D. (2015). Przechodzenie absolwentów studiów geograficznych na rynek pracy. Proces, czynniki, predykcja. Prace Monograficzne, 715. Kraków: Wydawnictwo Uniwersytetu Pedagogicznego im. Komisji Edukacji Narodowej, 268.

Rachwał, T., Wiedermann, K., Kilar, W. (2008). Wydajność i koszty pracy jako czynniki konkurencyjności przemysłu regionów Polski w Unii Europejskiej w ujęciu regionalnym. W: D. Ilnicki, K. Janc (red.). Przeksztatcenia regionalnych struktur funkcjonalno-przestrzennych: Europa bez granic - nowe wyzwania. Rozprawy Naukowe Instytutu Geografii i Rozwoju Regionalnego Uniwersytetu Wrocławskiego, 3, 79-89.

Rajman, J. (1972). Koncentracja kadr wysoko kwalifikowanych w Polsce. Czasopismo Geograficzne, $43(1), 57-65$.

Rajman, L. (1975). Zatrudnienie absolwentów geografii Uniwersytetu Jagiellońskiego w latach 1964-1971. Czasopismo Geograficzne, 46(2), 207-210.

Rajman, J., Krakowska, A., Skwirut, M.M., Szelińska-Kukulak, M. (1982). Rozmieszczenie geograficzne absolwentów szkół wyższych makroregionu południowo-wschodniego (rocznik 1979). Biuro Rady Nauki i Techniki Makroregionu Południowo-Wschodniego. 
Rogacki, H. (2007). Usługi. W: H. Rogacki (red.). Geografia społeczno-gospodarcza Polski. Warszawa: Wydawnictwo Naukowe PWN, 345-357.

Runge, J. (1990). Dynamika ludności i zatrudnienia w Polsce w latach 1975-1985. Czasopismo Geograficzne, 61(1/2), 21-30.

Runge, J. (1991). Dojazdy do pracy w przestrzennej strukturze powiązań miast województwa katowickiego. Prace Naukowe Uniwersytetu Ślaskiego w Katowicach, 1198. Katowice: Wydawnictwo Uniwersytetu Śląskiego.

Runge, J. (1995). Rynek pracy województwa katowickiego - demograficzno-społeczne aspekty funkcjonowania. Acta Universitatis Lodziensis, Folia Geographica, 19, 43-62.

Runge, J. (1996). Struktura rynku pracy regionu tradycyjnego i jego otoczenia na przykładzie województwa katowickiego. Prace Naukowe Uniwersytetu Śląskiego w Katowicach, 1592. Katowice: Wydawnictwo Uniwersytetu Śląskiego.

Runge, J. (2010). Rynek pracy województwa śląskiego. W: Procesy i struktury demograficzno-spoteczne na obszarze województwa śląskiego w latach 1998-2008. Katowice: Urząd Statystyczny, $111-157$.

Rutherford, D.T. (2009). Labor geography. W: International Encyclopedia of Human Geography. 12, $72-78$.

Rydz, E. (1999). Przekształcenia regionalnych rynków pracy na przykładzie Pomorza Środkowego. Stupskie Prace Matematyczno-Przyrodnicze, 12c, 155-180.

Rydz, E. (2001). Ekonomiczne i demograficzne uwarunkowania przemian strukturalnych na lokalnych rynkach pracy Pomorza. Wpływ integracji europejskiej na przemiany strukturalne obszarów o wysokim bezrobociu. Zeszyty Naukowe Wydziału Ekonomii i Zarządzania, 7. Koszalin: Politechnika Koszalińska, 227-248.

Rydz, E. (2006). Przemiany struktur społeczno-gospodarczych w okresie transformacji systemowej na Pomorzu Środkowym. Słupsk: Wydawnictwo Pomorskiej Akademii Pedagogicznej w Słupsku.

Rymarczyk, J. (1986). Migracja sity roboczej do krajów EWG i jej konsekwencje społeczno-gospodarcze. Poznań: Instytut Zachodni.

Stachowski, J. (1982). Zatrudnienie absolwentów geografii Uniwersytetu Mikołaja Kopernika w 1980 r. Acta Universitatis Nicolai Copernici Geografia, 17, 153-159.

Stryjakiewicz, T. (2007). Transformacja gospodarki w ujęciu strukturalnym i przestrzennym. W: H. Rogacki (red.), Geografia społeczno-gospodarcza Polski, Warszawa: Wydawnictwo Naukowe PWN, 165-285.

Szmielińska-Pietraszek, P., Szymańska, W. (2009). Analiza sytuacji długotrwale bezrobotnych w mieście i w powiecie słupskim w świetle badań. W: E. Rydz (red.). Analiza sytuacji dtugotrwale bezrobotnych na terenie powiatu stupskiego i miasta Stupska. Słupsk: Powiatowy Urząd Pracy, $109-126$.

Śleszyński, P. (2007a). Szacowanie liczby i rozmieszczenia pracujących w Warszawie. Przegląd Geograficzny, 79(3-4), 401-433.

Śleszyński, P. (2007b). Zmiany liczby bezrobotnych w gminach. Wiadomości Statystyczne, 2, 55-67.

Śleszyński, P. (2010). Studium szacunku liczby i rozmieszczenia pracujących w Krakowie. Biuletyn Komitetu Przestrzennego Zagospodarowania Kraju PAN, 243.

Śleszyński, P. (2012a). Kierunki dojazdów do pracy. Wiadomości Statystyczne, 11, 59-75.

Śleszyński, P. (2012b). Struktura przestrzenna dojazdów pracowniczych w Polsce w 2006 r. W: P. Rosik, R. Wiśniewski (red.). Dostępność i mobilność w przestrzeni. Warszawa: Instytut Gospodarki i Przestrzennego Zagospodarowania PAN, 23-33.

Śleszyński, P. (2014). Delimitation and typology of functional urban regions in Poland based on commuting, 2006. Geographia Polonica, 87(2), 317-320.

Tracz, M., Stanuch, J. (2011). Losy zawodowe absolwentów nauczycielskich studiów geograficznych Akademii Pedagogicznej w Krakowie. W: K. Potyrała (red.). Kompetencje czy kwalifikacje? Efekty kształcenia studentów kierunków przyrodniczych $w$ kontekście Krajowych Ram 
Kwalifikacji i badań na różnych etapach edukacyjnych. Kraków: Wydawnictwo Uniwersytetu Pedagogicznego, 37-44.

Werwicki, A. (1992). Zatrudnienie w usługach wybranych krajów środkowoeuropejskich pod koniec nakazowo-rozdzielczego systemu gospodarczego. Zeszyty Instytutu Geografii i Przestrzennego Zagospodarowania PAN, 10, 5-31.

Wiatrak, A.P. (1990). Zasoby sity roboczej w gospodarstwach rodzinnych, Warszawa: Wydawnictwo Naukowe PWN.

Więckowski, M. (1978). Stan zatrudnienia geografów w Polsce w 1976 r. Czasopismo Geograficzne, 49(3), 315-338.

Wiśniewski, R. (2012). Codzienne dojazdy do pracy - metodyczne aspekty badania wielkości i struktury odjazdów na przykładzie Białegostoku. Studia Lokalne i Regionalne, 3(49), 50-64.

Wójcik, M., Suliborski, A. (2014). Geografia społeczna w Polsce - geneza, koncepcje i zróżnicowanie problemowe, ze szczególnym uwzględnieniem studiów geograficzno-miejskich w ośrodku łódzkim. W: A. Suliborski, M. Wójcik (red.). Dysproporcje spoleczne i gospodarcze w przestrzeni Łodzi. Czynniki, mechanizmy, skutki. Łódź: Wydawnictwo Uniwersytetu Łódzkiego, 17-48.

Zioło, Z. (1974). Wpływ zatrudnienia w przemyśle na rozwój demograficzny miast województwa rzeszowskiego w latach 1937-1970. Folia Geographica. Series Geographica-Oeconomica, VII. Warszawa-Kraków: Państwowe Wydawnictwo Naukowe, 39-53.

Zioło, Z. (1993). Przemiany krajowych i regionalnych struktur bezrobocia w Polsce. Biuletyn Komitetu Przestrzennego Zagospodarowania Kraju PAN, 161, 41-62.

Zioło, Z. (1999). Transformacja struktur subregionalnych Polski Południowo-Wschodniej w okresie zmian systemu gospodarowania. Prace Komisji Nauk Ekonomicznych, 24, Kraków: Wydawnictwo Polskiej Akademii Nauk.

Danuta Piróg, dr, Instytut Geografii, Uniwersytet Pedagogiczny im. Komisji Edukacji Narodowej w Krakowie. Jest adiunktem w Instytucie Geografii Uniwersytetu Pedagogicznego w Krakowie. Jej aktualne zainteresowania naukowe dotyczą procesu przechodzenia osób z wyższym wykształceniem na rynek pracy, ze szczególnym uwzględnieniem absolwentów kierunku geografia. Proces ten D. Piróg bada zarówno w kontekście teorii rynku pracy, mechanizmów tego typu tranzycji w świetle procesów społeczno-gospodarczych, jak i z punktu widzenia rzeczywistego tempa oraz charakteru przejścia nowo promowanego absolwenta uczelni wyższej na rynek pracy, ustalonych na podstawie badań empirycznych. Dr Piróg swoje doświadczenie naukowe pogłębiała przez czynny udział w krajowych i międzynarodowych projektach badawczych lub kierowanie nimi. Aktualnie zajmuje się przede wszystkim wielowymiarowymi analizami czynników warunkujących procesy tranzycji absolwentów szkół wyższych na rynek pracy.

Danuta Piróg, Ph.D., is an assistant professor at the Pedagogical University of Cracow (Institute of Geography). Her current research interests are focused on the transition of higher education graduates' from education to the labour market with a particular concern on geography students. She explores these issues both through labour market theories and mechanisms of this type of transition in the light of socio-economic changes and by empirical survey devoted to higher education graduates' transition into the labour market. She has been a member of various scientific projects on national and European level. Currently her scientific surveys are devoted to multidimensional analysis of determinants of $\mathrm{HE}$ graduates transition into the labour market.

\section{Adres/address:}

Uniwersytet Pedagogiczny

Instytut Geografii

ul. Podchorążych 2, 30-084 Kraków, Polska

e-mail: dbutryn@up.krakow.pl 